Catterina Ferreccio 1

Claudia Gonzalez Psych 1

Vivian Milosavjlevic Stat 1

Guillermo Marshall Gredis 2

Ana María Sancha 3

\title{
Lung cancer and arsenic exposure in drinking water: a case-control study in northern Chile
}

\author{
Cáncer de pulmón y exposición a arsénico \\ en el agua potable: un estudio de casos \\ y controles en el norte de Chile
}

1 Grupo para el Desarrollo de la Investigación en Salud (GREDIS). Casilla 52750, Correo Central, Santiago, Chile. 2 Departamento Estadística, Facultad de Matemáticas, Pontificia Universidad Católica de Chile.

Vicuña Mackenna,4860, Santiago 22, Casilla 306, Chile

3 Facultad de Ciencias Físicas y Matemáticas, Universidad de Chile. Av. Blanco Encalada,2120 4o piso of. 17,Santiago, Chile
Abstract In some Chilean cities, levels of arsenic (As) in drinking water reached $800 \mu \mathrm{g} / \mathrm{L}$ between 1950 and 1970, while current level s are $40 \mu \mathrm{g} / \mathrm{L}$. To evaluate the causal role of this exposure in I ung and bladder cancers, we conducted a case-control study in Regions I, II, and III of the country. From 1994 to 1996, cases diagnosed as lung cancer and two hospi tal controls were entered in thestudy; one control was a patient with a cancer, while the other was a patient without cancer, both conditions unrel ated to As. Controls were matched with cases by age and sex. A standard survey contai ning questions about resi dence, empl oyment, health history, was administered to study subjects. Data on As concentrations in water were obtained from records of the municipal water companies. A total of 151 lung cancer cases and 419 controls ( 167 with cancer and 242 without cancer) were en rolled. Median level of li fetime As exposure was significantly higher among cases, with a clear dose-response relationship between mean As exposure levels, with an OR (95\% Cl) of: 1, 1.7 (0.5-5.1), 3.9 (1.2-13.4) , 5.5 (2.2-13.5), and 9.0 (3.6-22) for strata one to five respectively. This study provides new evidencethat As in drinking water can cause internal cancers and gives an estimate of the form of this relationship.

Key words Lung Neoplasms; Environmental Exposure; Arsenic

Resumen En algunas ciudades de Chile, entre 1950 y 1970, los niveles de arsénico (As) en el agua potablealcanzaron los $800 \mu \mathrm{g} / \mathrm{l}$, estando hoy en $40 \mu \mathrm{g} / \mathrm{l}$; para eval uar el rol de esta exposición, sellevó a cabo este estu di o de casos de cáncer de pulmón y controles en las Regiones I, II y III. Entre 1994 y 1996, se ingresaron casos de cáncer de pulmón y dos control es hospi tal arios: un control, un paciente con cáncer y el otro, un paciente sin cáncer, ambos diagnósticos no relacionados con arsénico. Los control es fueron pareados grupalmente por edad y sexo con los casos. A cada sujeto, se le apli có una encuesta estandarizada sobre resi dencia, empleo y sal ud. La información sobre niveles de As en el agua provi no de registros de las compañías de agua. Se ingresaron 151 casos de cáncer pulmonar y 419 controles (167 con cáncer y 242 sin cáncer). La mediana deAs en el agua potable a lo largo de la vi da fue significativamente mayor entre los casos, con una clara relación dosis-respuesta entre el promedio de As y el riesgo, con OR (95\% IC) de 1, 1,7 $(0,5-5,1), 3,9(1,2-13,4), 5,5(2,2-13,5)$, y $9,0(3,6-22)$ para los estratos 1 al 5, respectivamente. Este estudio provee nueva evidencia sobre el rol causal del As en el agua potableen cánceres internos y sobre la forma dela relación entre exposi ción y riesgo de cáncer.

Palabras clave Neoplasias de Pulmón; Exposición Ambiental; Arsénico 
Introduction

Humans are exposed to organic and inorganic arsenic (As) from environmental and occupational sources. The main source of exposure (in terms of number of people affected) is environmental, naturally occurring inorganic As in drinking water (Hesse et al., 1990; Bates et al., 1995). Occupational exposure affects workers engaged in smelting and refining copper, gold, and lead ores and in the production of agricultural pesticides, pigments, dyes, glass, semiconductors, and various pharmaceutical substances, including the possibility of high exposure to airborne arsenic (WHO, 1981). Arsenic has been implicated as one of the main risk factors for skin, lung and bladder cancer deaths in northern Chile, where residents have used water with high As content for decades. In this region, besides the naturally occurring arsenic, copper smelting has been implicated as a risk factor for workers (Ferreccio et al.,1995).

The aim of this study is to assess the doseresponse relationship between mean arsenic exposure in drinking water and risk of lung cancer among residents in northern Chile.

M aterial and methods

Study areas

Northern Chile includes Regions I-III. This area contains the Atacama Desert, known as the mining zone of the country. The desert is 1,700 $\mathrm{km}$ long and an average of $300 \mathrm{~km}$ wide, with a population of 900,000 . The main occupations are related to the mining and fishing industries. The highest exposure to arsenic has been in Region II, through drinking water.

Measurement of exposure

Water companies supply the region with well or surface water. They supply the same water to all households in a given city. In these regions, $100 \%$ of the urban households are covered by the municipal water utilities systems. The utilities companies are required to perform detailed chemical tests of the water, including As levels, at least once a year. We collected data on As levels from 1950 to 1996 for the 350 counties from the entire country.
Identification of lung cancer cases

Nurses were recruited for the study and trained in interviewing techniques in each city of northern Chile (Arica, Iquique, Copiapó, Antofagasta). They were responsible for identifying cases in the hospitals. In the main hospitals, interviewers made daily visits to the admissions departments and to pathology laboratories to identify any patients admitted with lung cancer. Patients not identified until after discharge were visited and interviewed in their homes.

Eligible cases were all those diagnosed with lung cancer in the study region between November 1994 and July 1996, confirmed by biopsy, and whose first diagnosis was either at the current hospitalization, or no more than one year before the current hospitalization.

\section{Selection of controls}

Two controls were selected for each lung cancer case from patients admitted to hospitals within one month of the index case. The first control (for control group A) was selected from patients with another cancer, unrelated to arsenic (Smith et al., 1988). Cancers of the liver, skin, kidney, bladder, and prostate were excluded. The second control (for control group B) was selected from patients with a diagnosis unrelated to arsenic and excluding cancer. $\mathrm{Pa}$ tients admitted with cardiovascular, skin, or neurological conditions were excluded. Controls were not matched by hospital, since exposure is closely related to the region in which patients resided. Instead, eligible controls included all patients admitted to any hospital in the whole study region. The number of patients admitted to each hospital in 1994 was first identified, and a frequency distribution of numbers of admissions by hospital was calculated. Controls were selected to result in the same frequency distribution as those for admissions. Thus, for each index case a control was selected as a hospital admission within a month of the index case, of the same sex and within four years of the case's age.

Data collection

The nurse administered a structured questionnaire to collect information for all subjects, including: socioeconomic status (SES), lifetime residential history, occupational and health history, and smoking. To validate responses, a proxy questionnaire was applied to a family or close person to the subject. Nurses also conducted a physical exam in all study subjects 
(looking for As-related lesions) and reviewed clinical records to register all other health conditions.

A letter of consent was read to all study subjects, explaining the method of the study and the general objective. Only those who accepted and were able to answer the one-hour interview were included in the study.

\section{Statistical analysis}

Arsenic Exposure: Histories of residential and work addresses were used to derive mean arsenic concentration in drinking water. This lifetime average was the mean level across all residential levels and periods. Lifetime As exposure was analyzed as a continuous and categorical variable, where 5 exposure strata were developed based on subject distribution. The lowest exposure category was used as a reference to derive Odds Ratios (ORs) using unconditional regression analysis with the Stata Program. ORs were estimated with univariate as well as multivariate models, controlling by age, sex, SES, smoking, and occupational history. Results from skin tests were combined with data from medical records to classify study subjects in 4 categories: no lesions, pigmentation, keratoses, and skin cancer. Analyses were repeated separately for each type of control. A separate model was derived for women and men. A test for trend was done based on Cochran (1954).
Results

During the 20 months of enrollment, 217 new lung cases were diagnosed in the hospitals. A total of 151 (70\%) had complete information to enter into the study. There were very few refusals among cases and controls (less than $5 \%$ ). The main reasons for not entering the study were that the patients were not at the hospital at the moment we attempted to contact them, had moved, or were too sick to fill out the questionnaire. A total of 419 controls entered the study, achieving the goal of one control per case for type B controls (252; 0.9 controls per case) but not for type A controls (167; 0.6 controls per case).

Lifetime mean As exposure in cases and controls is presented in Table 1. The data are arranged in five exposure strata, and crude and adjusted ORs are given for each stratum. Adjusted ORs were obtained with a logistical regression model (Stata) including sex, age, and smoking status.

There is a clear dose-response relationship (Cochrane test $\mathrm{p}<0.05$ ) that is stronger when adjusted by age, sex, and smoking status (ever or never). OR estimations reaches statistical significance when As concentration was above $0.03 \mathrm{mg} / \mathrm{l}$. When control A was used as the reference group, the ORs were even higher than with control B (Table 2). Nevertheless, both express the same type of effect. Most of the analysis was done with combined controls.

When males and females were analyzed separately, males showed higher and more significant ORs: $1,2.2(0.6-8.7), 4.1(0.9-17), 7.1$ (2.3-21), and 9.7 (3.2-29) for strata 1 through 5 , respectively, compared with females: ORs: $1,0.9$ (0.1.-6.3), 3.6 (0.4-32.6), $2.7(0.5-14.1)$, and 7.1

Table 1

Lifetime arsenic levels in drinking water for lung cases and controls. Average As 1930-1994.

\begin{tabular}{|c|c|c|c|c|}
\hline Mean (mg/L) & Controls ( $\mathrm{N}: 419)$ & Cases (N:151) & $\begin{array}{l}\text { OR (crude) } \\
(95 \% \text { C I) }\end{array}$ & OR adjusted \\
\hline $0-0.01$ & 70 & 6 & 1 & 1 \\
\hline $0.01-0.029$ & 68 & 9 & $\begin{array}{r}1.5 \\
(.5-4.6)\end{array}$ & $\begin{array}{r}1.7 \\
(0.5-5.1)\end{array}$ \\
\hline 0.03-0.049 & 24 & 7 & $\begin{array}{r}3.4 \\
(1.04-11.1)\end{array}$ & $\begin{array}{r}3.9 \\
(1.2-13.4)\end{array}$ \\
\hline $0.05-0.199$ & 130 & 52 & $\begin{array}{r}4.7 \\
(1.9-11.4)\end{array}$ & $\begin{array}{r}5.5 \\
(2.2-13.5)\end{array}$ \\
\hline $0.20-0.40$ & 127 & 77 & $\begin{array}{r}7.1 \\
(2.9-17.1)\end{array}$ & $\begin{array}{r}9.0 \\
(3.6-22.0)\end{array}$ \\
\hline
\end{tabular}


Lifetime arsenic level in drinking water for lung cases and each type of control. Average As 1930-1994.

\begin{tabular}{|c|c|c|c|c|c|}
\hline Mean As (mg/L) & $\begin{array}{c}\text { Control A } \\
(\mathrm{N}: 167)\end{array}$ & $\begin{array}{c}\text { Control B } \\
(\mathrm{N}: 242)\end{array}$ & $\begin{array}{c}\text { Cases } \\
(\mathrm{N}: 151)\end{array}$ & $\begin{array}{c}\text { OR } \\
\text { Controls A }\end{array}$ & $\begin{array}{c}\text { OR } \\
\text { Controls B }\end{array}$ \\
\hline $0-0.01$ & 30 & 40 & 6 & 1 & 1 \\
\hline $0.01-0.029$ & 27 & 41 & 9 & $\begin{array}{r}2.0 \\
(0.6-6.7)\end{array}$ & $\begin{array}{r}1.5 \\
(0.5-4.7)\end{array}$ \\
\hline $0.03-0.049$ & 7 & 17 & 7 & $\begin{array}{r}5.7 \\
(1.4-23.5)\end{array}$ & $\begin{array}{r}3.1 \\
(0.9-11.1)\end{array}$ \\
\hline $0.05-0.199$ & 59 & 71 & 52 & $\begin{array}{r}5.3 \\
(1.9-14.3)\end{array}$ & $\begin{array}{r}5.7 \\
(2.1-14.7)\end{array}$ \\
\hline $0.20-0.40$ & 44 & 83 & 77 & $\begin{array}{r}11.7 \\
(4.3-32.0)\end{array}$ & $\begin{array}{r}7.4 \\
(2.9-18.9)\end{array}$ \\
\hline
\end{tabular}

Table 3

Skin status among study subjects.

\begin{tabular}{lrrrr}
\hline Skin Status & Controls (\%) & Cases (\%) & OR & $(\mathrm{Cl} \mathrm{95 \% )}$ \\
\hline No As lesion & $384(92)$ & $101(66)$ & 1 & \\
Pigmentation & $26(6)$ & $33(22)$ & 4.8 & $(2.7-8.8)$ \\
Keratosis & $8(2)$ & $12(8)$ & 5.7 & $(2.1-15.8)$ \\
Cancer & $1(0.2)$ & $5(3.3)$ & 19.0 & $(2-400)$ \\
Any As lesion & $35(8)$ & $50(33)$ & 5.4 & $(3.0-9.1)$ \\
\hline
\end{tabular}

(1.6-7.4) for strata 1 to 5, respectively. Both series present the same type of relationship between exposure and cancer risk, and they were thus combined for most of the analysis.

Skin lesions related to arsenic (Table 3) were more frequent among cases (34\%) than among controls (8\%), with a linear trend from no lesions to skin cancer. We did not conduct a validity study of the nurses' diagnoses or the potential bias, given that they were not blinded to the subjects' conditions.

Table 4 presents study groups classified as ever or never smoked. Odds ratios of As exposure are presented separately for the two groups. There is a slightly higher OR among the smokers.

Average number of packs of cigarettes smoked per year by cases and controls showed a clear dose-response relationship, with an OR of 1,1.8, 4.0, 5.4, and 14 for the strata: 0; 1-90; 91-180; 181-400; and $>400$ packs of cigarettes/ year, respectively. Males and females showed a similar curve, but there were no females in the highest exposure group

\section{Discussion}

Most of the association between arsenic and cancer risk in Chile has been based on ecological data showing a correlation between excess risk of some cancers and high levels of As in drinking water (Ferreccio et al., 1997). Ecological studies have the potential for many confounders such as other risk factors, different diagnostic criteria, and hospitalization rates, amongst others.

This individual-based study intended to address some of these limitations by estimating the exposure level for each subject based on personal history and controlling for all known confounders.

Previous evidence of the association between As and internal cancers had been questioned because all the evidence was based mainly on Taiwanese data, which might have been a highly susceptible population (Bates et al., 1992; Smith et al., 1992; Brown \& Chen, 1995; Chiou et al., 1995; Mushak \& Crocetti, 1995). This study confirms Taiwanese findings in a very different context. This is the first study of this kind in Chile and supported the ecological evidence as well as previous studies done elsewhere.

Among the limitations of this study is the potentially incomplete case identification. In fact, some cases in high socioeconomic groups may have been missed. When members of this group develop severe health conditions like suspected cancer, they seek medical care in the Greater Metropolitan Area. There is no reason to believe that this group of potential cases will have a different exposure rate to arsenic than the cases from the general population, since every household gets the same wa- 
Risk of lung cancer and exposure to arsenic by smoking status.

\begin{tabular}{|c|c|c|c|c|c|c|}
\hline \multirow{2}{*}{$\begin{array}{l}\text { Lifetime average } \\
\text { As drinking water } \\
(\mathrm{mg} / \mathrm{L})\end{array}$} & \multicolumn{3}{|c|}{ Never smoked } & \multicolumn{3}{|c|}{ Ever smoked } \\
\hline & $\begin{array}{c}\text { Controls } \\
189\end{array}$ & $\begin{array}{c}\text { Cases } \\
30\end{array}$ & OR & $\begin{array}{c}\text { Controls } \\
230\end{array}$ & $\begin{array}{c}\text { Case } \\
121\end{array}$ & OR \\
\hline$<0.001$ & 25 & 1 & 1 & 45 & 5 & 1 \\
\hline $0.001-0.029$ & 28 & 1 & 1.1 & 40 & 8 & 1.9 \\
\hline $0.03-0.049$ & 10 & 0 & inc & 14 & 7 & 5.1 \\
\hline $0.05-0.199$ & 59 & 11 & 5.7 & 71 & 41 & 5.4 \\
\hline$>0.200$ & 67 & 17 & 8.3 & 60 & 60 & 9.2 \\
\hline
\end{tabular}

ter in urban areas, regardless of socioeconomic status.

Another limitation relates to the exposure identification. Although arsenic exposure data were thorough, there were some years with no data. This incompleteness could lead to over or underestimation of exposure. The exposed areas have the most complete data series, so fluctuations in exposure levels are well-documented. The main distortion in estimates could affect the comparison group, i.e., the control groups. Since As can affect any organ system, diseased patients may have been more exposed to arsenic than the general population, thus producing an underestimation of the real risk.

\section{Acknowledgements}

The authors are grateful to Dr. Allan Smith for his review of the manuscript.
Thus, our results may be a very conservative estimation of the real risk of As in drinking water.

There has also been a debate about the form of the dose-response relation between arsenic and cancer risk (Hertz-Piccioto \& Smith, 1993; Wu et al., 1989). This study supports the linearity assumption for this relationship

The safety level for arsenic in drinking water established by the US EPA (USA EPA, 1988) and by the Chilean Ministry of Health is 0.05 $\mathrm{mg} / \mathrm{L}$, but the current WHO recommendation is much lower $(0.01 \mathrm{mg} / \mathrm{L})$. This study supports the assertion that As is an etiologic factor for internal cancers and that the current norm for As levels could be unsafe.

\section{References}

BATES, M.; SMITH, A. \& HOPENHAYN-RICH, C., 1992. Arsenic ingestion and internal cancers: a review. American Journal of Epidemiology, 135:462-474.

BATES, M.; SMITH, A. \& CANTOR, K., 1955. Case-control study of bladder cancer and arsenic in drinking water. American Journal of Epidemiology, 141: 523-530.

BROWN, K. \& CHEN, C. H., 1995. Significance of exposure assessment to analysis of cancer risk from inorganic arsenic drinking water in Taiwan. Risk Analysis, 15:475-483.

CHIOU, H.; HSUEH, Y.; LIAW, K. F.; HORNG, S. F.; CHIANG, M. H.; PU, Y. S.; LIN, J. S.; HUANG, C. H. $\&$ CHEN, C. J., 1995. Incidence of internal cancers and ingested inorganic arsenic: a seven-year follow-up study in Tai wan. Cancer Research, 55: 1296- 1300.

COCHRAN, W., 1954. Some methods for strengthening the common Chi2 tests. Biometrics, 10:417451 
FERRECCIO, C.; GONZALEZ, C.; SOLARI, J. \& NODER, C., 1995. Cáncer broncopulmonar entre trabajadores expuestos a arsénico: un estudio de casos y controles. Revista Médica deChile, 124:119-123.

FERRECCIO, C.; GONZALEZ, C.; MILOSAVJLEVIC, V.; MARSHALL, G. \& SANCHA, A. M., 1997. Impacto en Salud Atribuible a Exposición a Arsénico: Un Estudio Ecológi co. InformeFinal FONDEF Proyecto 2-24. Santiago: Facultad de Ciencias Físicas y Matemáticas, Universidad de Chile.

HERTZ-PICCIOTTO, I. \& SMITH, A., 1993. Observations on the dose-response curve for arsenic exposure and lung cancer. Scandi navian Journal of Work and Environmental Health, 19:217-226.

HESSE, J.; JANUS, J.; KRAJN C, E. \& KROESE, E., 1990. Integrated Criteria Document Arsenicum Effects. The Hague: National Institute of Public Health and Environmental Protection.

MUSHAK, P. \& CROCETTI, A., 1995. Risk and revisionism in arsenic cancer risk assessment. Environmental Health Perspectives, 103:684-688.
SMITH, A; PEARCE, N. \& CALLAS, P., 1988. Cancer case-control studies with other cancers as controls. International Journal of Epidemiology, 17: 298-309.

SMITH, A.; HOPENHAYN-RICH, C.; BATES, M. N.; GOEDEN, H. M.; HERTZ-PICCIOTO, I.; DUGGAN, H. M.; WOOD, R.; KOSNETT, M. J. \& SMITH, M. T., 1992. Cancer risk from arsenic in drinking water. Environmental Health Perspectives, 97:259-267.

USA EPA (United States Environmental Protection Agency), 1988. Evaluation of the Potential Carcinogenicity of Arsenic and Inorganic Compounds. Washington, D.C.: Carcinogen Assesment Group, Office of Health and Environmental Assessment.

WU, M. M.; KUO, T.; HWUANG, Y. \& CHEN, C. J., 1989. Dose-response relation between arsenic concentration in well water and mortality from cancers and vascular diseases? American Journal of Epidemiology, 130:1123-1132.

WHO (World Health Organization), 1981. Environmental Health Criteria 18: Arsenic. Geneva: WHO. 